UDC 631.432.2:633.16:631.582.2

DOI https://doi.org/10.32851/2226-0099.2020.113.19

\title{
THE INFLUENCE OF DIFFERENT PRECEEDING CROPS OF SPRING BARLEY ON SPRING RESERVES OF AVAILABLE MOISTURE WHEN GROWN IN SHORT-TERM CROP ROTATIONS
}

\author{
Usyk S.V. - Candidate of Agricultural Science, Associate Professor, \\ Associate Professor at the Department of General Agriculture, \\ Uman National University of Horticulture \\ Yeshchenko V.O. - Doctor of Agricultural Science, \\ Professor at the Department of General Agriculture, \\ Uman National University of Horticulture \\ Karnauh O.B. - Candidate of Agricultural Science, \\ Associate Professor at the Department of General Agriculture, \\ Uman National University of Horticulture
}

The article deals with the results of research on the influence of sugar beet, soybean, maize and spring barley on the spring reserves of available moisture under spring barley when growing it in short-term crop rotations. It was found that the amount of moisture was different after different preceding crops, in the individual soil layers and under the years of research.

In particular, in 2011 in the soil layer of 0-100 cm the reserves of available moisture were almost the same after sugar beet and maize - 140.7 and $143.1 \mathrm{~mm}$, root-containing soil layer respectively, and after soybeans and under resowing - 147.7 and $149.2 \mathrm{~mm}$. The same was observed in the soil layers of 100-160 cm.

These differences were more contrasting in 2012. In the 0-100 cm layer, the least water was after the "sugar crops" - $132.7 \mathrm{~mm}$. And after soybean it was $21 \mathrm{~mm}$ higher. Maize and spring barley contributed the most to the accumulation of moisture -168.3 and $161.8 \mathrm{~mm}$, respectively. In the layers of 100-160 cm, the moisture reserves after soybean and maize were almost the same and occupied an intermediate position between the lowest value $(53.0 \mathrm{~mm})$ after sugar beets and the highest value $(95.1 \mathrm{~mm})$ after barley resowing.

In 2013, in the soil layer 0-100 cm, the least water was observed after the sugar crops$132.0 \mathrm{~mm}$. Soybeans and maize provided 22.6-24.6 $\mathrm{mm}$ more moisture accumulation than beets. And the leader in the ability to promote moisture accumulation in the soil this year was the re-sown spring barley. Here, the reserves of available moisture reached $162.1 \mathrm{~mm}$, which was $30.1 \mathrm{~mm}$ or $22.8 \%$ more than compared with the control.

In the deeper soil layer of 100-160 cm, the difference in moisture reserves among all preceding crops was not more than $7.3 \mathrm{~mm}$. But, despite this, again the last place among preceding crops had sugar beets $(93.4 \mathrm{~mm})$, and the first place - spring barley $(100.7 \mathrm{~mm})$. Soybeans and maize again occupied the intermediate place and were equivalent to each other.

Three-year average, in the soil layer of 0-100 cm, the lowest amount of available moisture was after sugar beet - $135.1 \mathrm{~mm}$. After other preceding crops the reserves were 16.9-22.6 $\mathrm{mm}$ more. Soybeans, maize and spring barley turned out to be almost equivalent. In the soil layer of 100-160 cm there was the same tendency but with some insignificant deviations.

In the soil layer of 0-160 cm, on average over three years, the lowest amount of moisture was observed after sugar beet and the highest after spring barley. Soybeans and maize occupied an intermediate position

Key words: available moisture, preceding crops, spring barley, sugar beet, soybean, maize, short-term crop rotations.

Усик С.В., Сщенко В.О., Карнаух О.Б. Вплив різних попередників ячменю ярого на весняні запаси доступної вологи під час вирощування в короткоротаційних сівозмінах

У статті наведено результати досліджень впливу буряка цукрового, сої, кукурудзи та ячменю ярого на весняні запаси доступної вологи під ячменем ярим під час вирощування його в короткоротаційних сівозмінах. Установлено, щзо кількість вологи була неоднакова після різних попередників в окремих шарах грунту, а також за роками досліджень. 
Зокрема, у 2011 рочі в шарі трунту 0-100 см запаси доступної вологи були практично однаковими після буряка иукрового та кукурудзи - 140,7 і 143,1 мм відповідно, а також після сої та в повторному посіві - 147,7 і 149,2 мм. Те ж саме помічено також і в шарах трунту 100-160 см.

Більш контрастними різничями виділявся 2012 рік. У шарі 0-100 см найменше води було після «иукроносія»-132,7 мм. А після сої ї̈ було більше на 21 мм. Найбільше накопиченню вологи сприяли кукурудза та ячмінь ярий - 168,3 і 161,8 мм відповідно. У шарах 100-160 см запаси вологи після сої та кукурудзи були практично однаковими й займали проміжне становище між найменшим (53,0 мм) після буряків иукрових і найбільшим (95,1 мм) у повторному посіві ячменю значеннями.

У 2013 роиі в шарі трунту 0-100 см найменше води помічено знову ж таки після иукроносної культури - 132,0 мм. Соя та кукурудза забезпечили накопичення вологи на 22,624,6 мм більше, ніж буряки. А лідером за здатністю сприяти вологонакопиченню у трунті виступив у иьому році повторний посів ячменю ярого. Тут запаси доступної вологи сягали 162,1 мм, ще проти контролю було більще на 30,1 мм або ж на 22,8\%.

У глибшому шарі трунту 100-160 см різниия запасів вологи між усіма попередниками була не більшою за 7,3 мм. Але, незважаючи на це, знову останнє місие серед попередників займали буряки иукрові (93,4 мм), а перше - ячмінь ярий (100,7 мм). Соя та кукурудза знову займали проміжне місие та були рівнозначними між собою.

У середньому за три роки в шарі трунту 0-100 см найменща кількість доступної вологи була після буряка иукрового - 135,1 мм. Після інших попередників запаси були на 16,9-22,6 мм більшими. Соя, кукурудза та ячмінь ярий між собою виявились практично рівнозначними. В шарі трунту 100-160 см була така ж сама тенденція, але з деякими незначними відхиленнями.

У шарі трунту 0-160 см у середньому за три роки найменша кількість вологи була помічена після буряка цукрового, а найбільша - після ячменю ярого. Соя та кукурудза займали водночас проміжне становище.

Ключові слова: доступна волога, попередники, ячмінь ярий, буряк иукровий, соя, кукурудза, короткоротачійні сівозміни.

Formulation of the problem. Full provision of the population with food is possible only when there is livestock production. In turn, effective animal husbandry is not possible without a complete dietary grain-fodder feed. And among all the grain-fodder crops, spring barley occupies one of the first places and has a significant share in the structure of sown areas of various farms, from the wholesale farms to individual farmers.

Taking into account the fact that in the conditions of dry land farming the agricultural crops productivity largely depends on the conditions of soil moisture supply, the research objective was to establish the influence of the proceeding crops of spring barley on the available moisture reserves, which in turn may have some impact on yields in the years of insufficient precipitation.

Analysis of recent research and publications. During the years of land reform in the countryside, many leased, farming and other enterprises with relatively small areas of land have appeared, where the use of once recommended multi-field crop rotations becomes impractical. Hence, as a rule, crop rotations have become short-term, and it has become more difficult or almost impossible for all crops to find the recommended proceeding crops [1]. And the important element of the spring barley growing technology, according to many researchers, is the choice of the proceeding crop [2-5]. The sufficient available moisture in the soil after the proceeding crop's growing can be one of the determining factors influencing the growing conditions of the next crop, and in conditions of unstable and insufficient moisture, it is the most important [6].

Setting a task. The research was conducted on the basis of a stationary experiment of the Department of General Agriculture, which was established in all the fields in autumn 1991 and spring 1992. In 2010, it was reformed by changing the sequence of individual crop rotations and the inclusion of soybean legumes. 
The experiment includes 17 variants of 5-field crop rotations, but for our research only four variants were taken into account (Table 1), in which the spring barley was grown after the following proceeding crops:

1. Sugar beets (check);

2. Soybeans;

3. Maize;

4. Spring barley.

Table 1

Scheme of the experiment

\begin{tabular}{|c|c|c|c|c|c|}
\hline \multirow{2}{*}{$\begin{array}{c}\text { Crop } \\
\text { rotation } \\
\text { number }\end{array}$} & First & Second & Third & Fourth & Fifth \\
\cline { 2 - 6 } & spring barley & maize & soybeans & spring barley & sugar beets \\
\hline 6 & maize & spring barley & soybeans & spring barley & sugar beets \\
\hline 7 & maize & soybeans & maize & spring barley & sugar beets \\
\hline 11 & maize & soybeans & spring barley & spring barley & sugar beets \\
\hline 14 & \multicolumn{7}{c}{} \\
\hline
\end{tabular}

The experiment is repeated three times, the placement of variants is consistent. The cultivation area of the plots is $168 \mathrm{~m}^{2}$, the accounting area is $80 \mathrm{~m}^{2}$. Growing techniques are common for the region.

Determination of soil moisture was carried out to a depth of $160 \mathrm{~cm}$ at the beginning and end of the growing season of spring barley by thermostatic-weight method, followed by recalculation of available moisture reserves.

Outlining the main research material. As the results of our research showed (Table 2), the water reserves in the 160-centimeter layer of soil were not the same in terms of proceeding crops, as well as in terms of years of research and individual layers of soil. For example, at the beginning of the spring barley vegetation in 2011 in the soil layer $0-100 \mathrm{~cm}$, the available moisture reserves were almost the same after sugar beets and maize -140.7 and $143.1 \mathrm{~mm}$ respectively, as well as after soybeans and in resowing $-147,7$ and $149.2 \mathrm{~mm}$. A similar trend was also observed in the lower soil layers of 100-160 cm. Although there were large reserves in the barley resowing $(89.5 \mathrm{~mm})$, but after other proceeding crops the difference was not more than $6.9 \mathrm{~mm}$. Therefore, in general, the same dependence is repeated in the $0-160 \mathrm{~cm}$ layer.

Table 2

Available moisture reserves under spring barley crops at the beginning of vegetation after different proceeding crops in different soil layers, $\mathbf{m m}$

\begin{tabular}{|c|c|c|c|c|c|c|c|c|}
\hline \multirow[b]{3}{*}{ Proceeding plants } & \multicolumn{6}{|c|}{ Year } & \multirow{2}{*}{\multicolumn{2}{|c|}{$\begin{array}{c}\text { Three-year } \\
\text { average }\end{array}$}} \\
\hline & \multicolumn{2}{|c|}{2011} & \multicolumn{2}{|c|}{2012} & \multicolumn{2}{|c|}{2013} & & \\
\hline & $\frac{8}{1}$ & 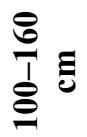 & $\stackrel{\Xi}{\varrho}$ & 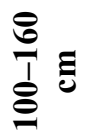 & $\frac{\Xi}{\varrho}$ & 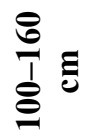 & $\frac{8}{\varrho}$ & 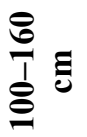 \\
\hline Sugar beets (check) & 140.7 & 82.6 & 132.7 & 53.0 & 132.0 & 93.4 & 135.1 & 76.3 \\
\hline Soybeans & 147.7 & 86.1 & 153.7 & 84.9 & 154.6 & 97.4 & 152.0 & 89.5 \\
\hline Maize & 143.1 & 83.8 & 168.3 & 85.7 & 156.6 & 96.7 & 156.0 & 88.7 \\
\hline Spring barley & 149.2 & 89.5 & 161.8 & 95.1 & 162.1 & 100.7 & 157.7 & 95.1 \\
\hline
\end{tabular}


Total reserves of available moisture in the soil layer $0-160 \mathrm{~cm}$ under spring barley crops at the beginning of the growing season after different proceeding crops, $\mathbf{m m}$

\begin{tabular}{|c|c|c|c|c|}
\hline \multirow{2}{*}{ Proceeding plants } & \multicolumn{3}{|c|}{ Year } & Three-year \\
\cline { 2 - 4 } & $\mathbf{2 0 1 1}$ & $\mathbf{2 0 1 2}$ & $\mathbf{2 0 1 3}$ & 211.4 \\
\hline Sugerage
\end{tabular}

A more contrasting difference in the available moisture reserves after different proceeding crops was in 2012. For example, at the beginning of the growing season in the layer of $0-100 \mathrm{~cm}$ the least water was after sugar beets $-132.7 \mathrm{~mm}$. After soybeans it was already $21 \mathrm{~mm}$ larger. And most of all, maize and spring barley contributed to the accumulation of moisture, after which the spring reserves of soil moisture increased to 168.3 and $161.8 \mathrm{~mm}$, respectively. In the deeper layers of $100-160 \mathrm{~cm}$, the moisture reserves after soybean and maize were almost the same and occupied an intermediate position between the lowest value $(53.0 \mathrm{~mm})$ after sugar beets and the highest value $(95.1 \mathrm{~mm})$ in barley re-sowing.

According to the total indices of available moisture reserves in the layer of $0-160 \mathrm{~cm}$, all proceeding crops can be placed in ascending order from smaller to larger as follows: sugar beets $(185.6 \mathrm{~mm})$, soybeans $(238.6 \mathrm{~mm})$, maize $(253.9 \mathrm{~mm})$ and barley $(256.9 \mathrm{~mm})$. As we can see, compared to the check on the experimental variants, the moisture increase was $28.6-38.4 \%$.

In contrast to the previous one, in 2013 the reserves of available moisture after the crops, different in biology and technology, were formed somewhat differently. For example, in the soil layer $0-100 \mathrm{~cm}$, the least water was observed again after the sugar crops $-132.0 \mathrm{~mm}$. Soybeans and maize provided 22.6-24.6 $\mathrm{mm}$ more moisture than beets. And the leader in the ability to promote moisture accumulation in the soil was the re-sowing of spring barley. Here, the reserves of available moisture reached $162.1 \mathrm{~mm}$, which was $30.1 \mathrm{~mm}$ or $22.8 \%$ more than before the check.

Some differences this year were also observed in the deeper soil layer of 100-160 cm. In particular, these are almost equivalent values of soil moisture, due to which the difference in moisture reserves between all proceeding crops was not more than $7.3 \mathrm{~mm}$. But, despite this, the last place among the proceeding crops was again occupied by sugar beets $(93.4 \mathrm{~mm})$, and the first one - by the spring barley $(100.7 \mathrm{~mm})$. Soybeans and maize again occupied an intermediate place and were equivalent to each other.

Three-year average, the lowest reserves of available moisture after sugar beets $135.1 \mathrm{~mm}$ - are clearly distinguished in the $0-100 \mathrm{~cm}$ layer. After the other proceeding crops, they were 16.9-22.6 mm larger. However, soybean, maize and spring barley were almost equivalent to the difference of no more than $5.7 \mathrm{~mm}$ in terms of the effect on spring soil moisture reserves in the upper meter layer. With some deviations, a similar trend was also observed in the layer of $100-160 \mathrm{~cm}$, where on average in 2011-2013 the smallest spring reserves of available moisture had the barley crops after sugar beets, they were slightly larger after maize and soybeans, and the largest - in resowing. 
As for the total moisture reserves in the layer $0-160 \mathrm{~cm}$, as can be seen from Table 3, they differed significantly from the proceeding crops by years with the only feature that they were relatively higher annually in resowing, and the lowest - after sugar beets. As for other proceeding crops, which occupied an intermediate place under the soil moisture reserves in the 160-centimeter layer, a slightly better position in 2011 was occupied by soybeans, and in 2012 - by maize. And in 2013 and on average for three years, these proceeding crops in terms of spring barley plants supply with soil moisture were equivalent with a difference of 1.3 and $3.2 \mathrm{~mm}$, respectively.

Conclusions. The best conditions for water availability of spring barley plants at the beginning of its vegetation are in the resowing, slightly worse after maize and barley, and the lowest moisture reserves in the layer of $0-160 \mathrm{~cm}$ had the sugar beet crops.

\section{REFERENCES:}

1. Сщенко В.О. Польові сівозміни України, якими їм бути: довго- чи короткоротаційними ? Збірник наукових пращьь Уманського НУС. Вип. № 89. Ч. 1: Агрономія. Умань, 2016. С. 43-49.

2. Дутченко 3.Я. Глущенко Л.Т. Зміна врожаю і показників якості зерна ярого ячменю під впливом попередників і строків сівби. Вісник СНАУ. 2008. № 2. C. 90-91.

3. Кулик І.О. Оптимізація мінерального живлення рослин ячменю ярого після різних попередників у північному Степу України. Бюл. Iн-mу сіл. госn-ва cmenової зони НААН України. 2014. № 6. С. 125-131.

4. Гирка А.Д., Кулик I.О., Андрейченко О.Г. Особливості формування врожайності вівса та ячменю ярого під впливом попередників і фону мінерального живлення. Бюл. Ін-ту сіл. госп-ва степової зони НААН України. 2013. № 4. С. 112-116.

5. Андрейченко О.Г. Продуктивність плівчастого та голозерного ячменів ярих залежно від норм висіву і попередника в умовах північного Степу. Бюл. Iн-ту сіл. госп-ва степової зони НААН України Бюлетень. 2013. № 4. С. 135-139.

6. Шевченко М.С., Шевченко О.М., Швець Н.В. Агродинаміка вологоспоживання залежно від технологічних факторів землеробства степової зони. Бюл. Ін-ту сіл. госп-ва степової зони НААН України. 2013. № 5. С. 130-134. 